\title{
Equal Educational Opportunity: The Limits of Constitutional Jurisprudence Undefined
}

\author{
Philip B. Kurland
}

The question to be faced here is whether the equal protection clause of the fourteenth amendment compels a state to afford equal educational facilities-instruction, counseling, housing, etc.-to all students attending the public schools within its domain, without regard to where they live, the wealth of their local community, or that community's desire to spend its assets on public education. Perhaps, if law were the science that some of its purveyors claim it to be, an unequivocal response could be forthcoming, even from me. Unfortunately, law has not attained the standards of an art, no less the certainty of a science. And so, in lieu of providing the statistical data or the equation that would afford a definitive answer, I shall write around the question rather than to it.

I do not, however, wish to lay claim to the timidity of an angel rather than the intrepidity of a fool, especially since I tread where others have tread before me. And so I begin with an answer, albeit an answer that I do not like. For, if law is, as Mr. Justice Holmes has told us, "nothing more ... [than] the prophecies of what the courts will do in fact," 1 or if, as Mr. Chief Justice Hughes once said, "the Constitution is what the judges say it is,"2 I am prepared to make the necessary prophecy. I should tell you then, with some assurance, that sooner or later the Supreme Court will affirm the proposition that a State is obligated by the equal protection clause to afford equal educational opportunity to all of its public school students. But I should also tell you that such a decision, if it comes sooner rather than later, will probably only be the creation of a greater problem and not a solution to this one.

Philip B. Kurland is Professor of Law, The University of Chicago. This paper will appear in a forthcoming book by the Center for Policy Study of the University of Chicago, entitled The Quality of INequality: Suburban aNd URban Public Schools.

1 O. W. Holmes, The Path of the Law, in Collected Legal Papers 167, 173 (1920).

2 Addresses and Papers of Charles Evans Hughes 185 (2d ed. 1916). 


\section{The Easy Case for Equal Educational Opportunity}

The case to support such a Supreme Court judgment as I predict is certainly a reasoned one, and for some already a persuasive one. The logic of its conclusion would be based on premises afforded by three lines of earlier Supreme Court decisions. Few of the Court's recent opinions are so rich in precedent as this one would be.

The argument has been spelled out in detail in Mr. Arthur Wise's book. ${ }^{3}$ The essentials that I repeat here are well documented by his study. And, since abbreviation is also likely to result in distortion, I commend the interested reader to a consideration of Mr. Wise's volume.

\section{A. The School Desegregation Gases}

The case starts, as so many do these days, with the opinion of the Court-one of its rare unanimous decisions-in the School Desegregation Cases. ${ }^{4}$ There the Court both established the importance of public education as a matter of constitutional law and the proposition that, whatever the intention of the framers of the fourteenth amendment, ${ }^{5}$ differences in skin color cannot justify racially segregated public educational facilities. Indeed, if we look at the language of the opinion, it would seem to answer the very question that is posed for discussion here. In Brown, the Court said: ${ }^{6}$

Today, education is perhaps the most important function of state and local governments. Compulsory school attendance laws and the great expenditures for education both demonstrate our recognition of the importance of education to our democratic society. It is required in the performance of our most basic public responsibilities, even service in the armed forces. It is the very foundation of good citizenship. Today it is a principal instrument in awakening the child to cultural values, in preparing him for later professional training, and in helping him to adjust normally to his environment. In these days, it is doubtful that any child may reasonably be expected to succeed in life if he is denied the opportunity of an education. Such an opportunity, where the state has undertaken to provide it, is a right which must be made available to all on equal terms.

That the Court did not think that it had provided a solution to

3 A. E. WISE, Rich Schools, Poor Schools (in press).

4 Brown v. Board of Educ., 347 U.S. 483 (1954).

5 See Bickel, The Original Understanding and the Segregation Decision, 69 Hanv. L. REv. 1 (1955).

6 347 U.S. at 493 . (Emphasis added.) 
our immediate problem is, however, made clear by the decision it reached in Griffin v. County School Board. ${ }^{7}$ There, a single county in Virginia had closed its public schools rather than desegregate them and had provided funds for the operation of "private" segregated schools. This, the Supreme Court said, Virginia could not do. While it conceded the possibility of allowing different local government units within a State to behave differently, the Court said that it could not allow such a difference to exist "on grounds of race and opposition to desegregation."s

In short, given the desegregation cases alone, it is not clear that discrimination among students that might result from the accident of boundaries of local government units is banned by the equal protection clause. In terms of geography, the invalid discrimination concept must be derived from another line of cases: the offspring of the justly famous, or infamous, ${ }^{9}$ Baker $v$. Carr..$^{10}$

\section{B. The Reapportionment Decisions}

The lesson of importance for the issue of equal educational opportunity to be learned from the reapportionment cases is that accidents of geography and the arbitrary boundary lines of local government can afford no basis for discrimination among citizens of a state. Each citizen's vote must weigh exactly as much as every other citizen's vote in the election of state legislators. These decisions turned a slogan into a constitutional doctrine: one man-one vote. What Dean Inge described as a vice of democracy, that it counts votes instead of weighing them, became, through the voice of the Supreme Court, American democracy's fundamental tenet. On differences in representation based on artificial boundaries of local government units, the Chief Justice said: "The resulting discrimination against those ... living in disfavored areas is easily demonstrable ...."11 Although the Court, at first, purported to agree that mathematical exactness was not required,

7377 U.S. 218 (1964).

$8 \mathrm{Id}$. at 231.

9 See Neal, Baker v. Carr: Politics in Search of Law, 1962 Sup. CT. Rev. 252.

10369 U.S. 186 (1962); Gray v. Sanders, 372 U.S. 368 (1963); Wesberry v. Sanders, 376 U.S. 1 (1964); Reynolds v. Sims, 377 U.S. 533 (1964); WMCA, Inc. v. Lomenzo, 377 U.S. 633 (1964); Maryland Comm. for Fair Representation v. Tawes, 377 U.S. 656 (1964); Davis v. Mann, 377 U.S. 678 (1964); Roman v. Sincock, 377 U.S. 695 (1964); Lucas v. Colorado Gen. Assembly, 377 U.S. 713 (1964). Professor Carl A. Auerbach provided a vigorous defense of the reapportionment cases. But he conceded that they should better have rested on the Constitutional guaranty of a republican form of government than on the equal protection clause. See Auerbach, The Reapportionment Cases: One Person, One Vote-One Vote, One Value, 1964 Sup. Cr. Rev. 1.

11377 U.S. at 563. 
it has yet to approve a reapportionment scheme in which any but the smallest deviation from a one-to-one ratio is shown to exist.

There are other principles enunciated in the reapportionment cases that are relevant to the equal educational opportunity concept. In addition to the proposition that discrimination based on geography is unconstitutional, the cases dispose of the argument that history or custom affords a basis for differentiating among citizens. No matter how long-standing the practice of allocating representatives by counties or other historic boundary lines, the practice must fall before the demand of the principle of "one man-one vote." These cases also suggest that what may be arbitrary for the states, and therefore unconstitutional, may nevertheless still be appropriate for the Nation. At least, they conceded that the disproportionate allocation of representation in the United States Senate, although based on the arbitrary lines supplied by state boundaries, is not yet subject to invalidation by the Supreme Court of the United States.

Thus far, the argument for a constitutional principle of equal educational opportunity based on the equal protection clause turns on two general propositions established by the Court. First, that discrimination in education by the state may not be based on color. Second, that the state may not discriminate on the basis of arbitrary geographical lines drawn to establish local government units. The last nail in the coffin of unequal educational opportunity is provided by a third series of cases from which an equally general proposition may be derived: governmental discrimination may not be based on wealth, at least if the discrimination is adverse to the poor.

\section{Indigent Defendants and the Administration of Criminal Justice}

The argument about the irrelevance of wealth to social justice is based on cases in the area of the administration of the criminal law. In the landmark case of Griffin v. Illinois, ${ }^{12}$ the Supreme Court held that an indigent defendant cannot be denied the same opportunity for appeal from an adverse judgment that is available to others simply because he cannot afford the price of a transcript of the trial proceedings. It did not rule that all defendants shall be provided with a transcript at the cost of the state, but rather that those who could not buy it for themselves must be given a transcript or its equivalent by the state. Otherwise, said the Court, an invidious discrimination between rich and poor would exist that would be violative of the equal protection clause.

The Griffin case was later used as a basis for establishing the rule

12351 U.S. 12 (1956). 
that the equal protection clause required a state to provide counsel on appeal to those who could not afford to hire their own. ${ }^{13}$ It is of some interest to our problem, as I shall try to show later, that the right to counsel at trial ${ }^{14}$ and before trial ${ }^{15}$ was not rested on any notion of equal protection of the laws but rather was developed as part of the concept of due process of law. That is, equality was not the primary cause for affording counsel but a notion of the minimum decencies demanded by our ideals of a fair trial.

\section{Some Random Comments on the Triquetrous Argument}

Before leaving the three-pillared argument for equal educational opportunity as a constitutional mandate derived from the equal protection clause, I should offer the uninitiated a little more information about the supporting cases. It should be noted, for example, that with regard to each of the three lines of cases what begins as a narrow decision supported by broad principle is soon utilized by the Court as authority for extending the rule's coverage to the limits of the principle. Thus, the Court clearly rested the Brown decision on the extraordinary need for non-discrimination by race in the area of education, even where separate but equal facilities were theoretically available. Very quickly, however, the principle of non-discrimination by race was expanded, without further explanation, to beaches, golf courses, buses, and parks. ${ }^{16}$ The right to a transcript established in Griffin $v$. Illinois was soon extended to other facilities thought necessary for appeals and post-conviction proceedings. ${ }^{17}$ The right to counsel at trial has also been extended to other portions of the criminal process and to matters that were once thought not to be included in the criminal process. ${ }^{18}$ And what began, in the reapportionment cases, as a demand for meaningful bases for distinguishing voting units soon became rigid and unbending requirements of one man-one vote. "Universal equality is not the test," said Mr. Justice Douglas, "there is room for weighting."19

\footnotetext{
13 Douglas v. California, 372 U.S. 353 (1963).

14 Gideon v. Wainwright, 372 U.S. 335 (1963). See A. Lewis, Gmeon's Trumpet (1964).

15 Miranda v. Arizona, 384 U.S. 436 (1966). See H. Friendly, Benchmarks, chs. 11-12 (1967); W. Schaefer, The Suspect AND Soctety (1967); Traynor, The Devils of Due Process in Criminal Detection, Detention, and Trial, 33 U. CHI L. REv. 657 (1966).

16 Mayor \& City Council of Baltimore v. Dawson, 350 U.S. 877 (1955), aff'g 220 F.2d 386; Holmes v. City of Atlanta, 350 U.S. 879 (1955), rev'g 223 F.2d 93; Gayle v. Browder, 352 U.S. 903 (1956), aff'g 142 F. Supp. 707; New Orleans City Park Improvement Ass'n v. Detiege, 358 U.S. 54 (1958), aff'g 252 F.2d 122.

17 Smith v. Bennett, 365 U.S. 708 (1961); Lane v. Brown, 372 U.S. 477 (1963).

18 Miranda v. Arizona, 384 U.S. 436 (1966); In re Gault, 387 U.S. 1 (1967); see Paulsen, The Constitutional Domestication of the Juvenile Court, 1967 SUP. Cr. REv. 233. 19369 U.S. at 244-45. "Contrary to the suggestion of my Brother HARLAN, the Court does not say or imply," said Mr. Justice Stewart, "that "state legislatures must be so struc-
} 
Shortly thereafter, however, the rule became, as Mr. Justice Stewart put it: "Within a given constituency there can be room for but a single constitutional rule-one voter, one vote." 20 In short, the three lines of cases would appear to have a capacity for expansion that some would analogize to hot-house plants and others to cancerous growths.

Finally, I think that the proposed Supreme Court ruling is in keeping with the spirit of the times. It is thoroughly in accord with what I have elsewhere denominated the Court's general drive toward egalitarianism, toward centralization of government authority, and toward the expansion of judicial power in realms theretofore foreclosed to it. ${ }^{21}$ And the prognosis for success is also supported by the readiness of the Court to propose simple answers for complex problems.

The logic of the case for equal educational opportunity is inexorable. It is a far stronger argument than most that carry the Court these days. If logic were the life of the law, the proposition that states must afford equal educational opportunity to all their students, given the premises, must be accepted as established. If, as is more likely, at least in the Supreme Court, the personal desires of the Justices or their will "to do good" underlies their judgments, there is even more reason to expect the quick announcement of a principle of equal educational opportunity. Thus, in offering approval of the Court's decision in Reitman v. Mulkey ${ }^{22}$ - the case striking down California's "Proposition Fourteen"-two of the Court's admirers, after demonstrating the absence of reason in the Court's opinions, nevertheless concluded: ${ }^{23}$

History-not the "original understanding," but tomorrow's history-will validate the decision as no satisfying doctrinal discourse could. It would have been unthinkable (we now conclude, looking backward) for the Court to have given legitimacy to the racism implied in Proposition 14. No onenot even professional writers about the Court-would have been impressed by the statement, "This is a bad law, but we are saying only that it is not unconstitutional." Thus judicial activism feeds on itself. The public has come to expect the Court to intervene against gross abuses. And so the Court

tured as to reflect with approximate equality the voice of every voter." "Id. at 265 . See the cases cited in note 10 supra.

20 Gray v. Sanders, 372 U.S. 368, 382 (1963). See Auerbach, The Reapportionment Cases: One Person, One Vote-One Vote, One Value, 1964 Sup. Cr. Rev. 1.

21 See Kurland, The Supreme Court, 1963 Term, Foreword: "Equal in Origin and Equal in Title to the Legislative and Executive Branches of Government," 78 Harv. L. Rev. 143 (1964).

22387 U.S. 369 (1967).

23 Karst \& Horowitz, Reitman v. Mulkey: A Telophase of Substantive Equal Protection, 1967 SUP. CT. REv. 39, 79. 
must intervene. The major break came in Brown v. Board of Education and the end of this spiral path is not in sight.

\section{The Uneasy Case for "Good Sense"}

Mr. Justice Holmes, whose aphorism about law, life, and logic has become a truism, went on from his pithy phrase to say: "The felt necessities of the time, the prevalent moral and political theories, intuitions of public policy, avowed or unconscious ... have had a good deal more to do than the syllogism in determining the rules by which men should be governed." 24 Elsewhere he noted: "Behind the logical form lies a judgment as to the relative worth and importance of competing legislative grounds, often an inarticulate and unconscious judgment, it is true, and yet the very root and nerve of the whole proceeding." ${ }^{25}$ And, in still another place he said, in a more optimistic vein than I would today venture, that "the law is administered by able and experienced men, who know too much to sacrifice good sense to a syllogism . . . ."26 What I propose to do in the remainder of this paper is to suggest some pertinent factors that do not go into the syllogism, some of the things that might be relevant to an exercise of "good sense."

\section{A. The Problem of Overkill}

My first difficulty with the equal educational opportunity proposal that is advocated is not that the logic of its argument proves too little, but rather that it proves too much. For the argument, in essence, demands the elimination of local governmental authority to choose the ways in which it will assess, collect, and expend its tax funds. To the extent that the argument is valid with reference to education, it is equally applicable to the small host of activities that are still left to local government control. Certainly, one must agree that education is a fundamental function of local government. But no less can be said about health services, police and fire services, water supply, public housing, parks and recreational facilities, transportation, welfare services, housing regulations, and what have you. Perhaps we are prepared to have the Supreme Court dictate a centralization of governmental power within the states in order to secure uniformity or equality of treatment in each of these categories. We may even be prepared to take the next logical step as well, the elimination of the disparities that may be attributable to the arbitrary geographic lines that constitute the boundaries of our states. For it may well be that the only answer to

24 O. W. Holmes, The Common Law 5 (Howe ed. 1963).

25 HOLMEs, supra note 1 , at 181.

26 Holmes, Common Carriers and the Common Law, 13 AM. L. REv. 609, 631 (1879). 
the demands of egalitarianism in government services is national rather than state control of these services. And, whether one likes this prospect or not, he has to acknowledge that it calls for a more fundamental change in our notions of local governmental authority than any that the Supreme Court has yet compelled. Statewide equality is not consistent with local authority; national equality is not consistent with state power.

Tax funds that are assessed, collected, and expended by the state may be amenable to a uniform rule of expenditure. So long as the taxing power and the spending power are left in the hands of local government units, however, for which, admittedly, only history and an outmoded concept of democracy speak, the required equality cannot be achieved. It is impossible both to leave discretion and choice to local government and expect a uniformity of treatment among all units of local government. Either the taxing power or the spending power, and probably both, will have to be transferred from local to state control. Perhaps the only barrier to such transfer is the prevailing tenet of "the liberals" creed" that, while reactionary state government is to be deplored and bypassed, local, especially local urban, governments are still admired as the best partners a progressive national government can find.

\section{B. The Problem of the Wrong Problem}

My second difficulty with the proposed constitutional doctrine of equal educational opportunity is that it is really not addressed to the issue that gives rise to the demand for the rule. I do not think that it is generally believed that the best of our public school systems is providing too good an educational opportunity, that communities like Scarsdale, New York, or New Trier Township in Illinois are putting too much of their resources into their educational programs. The real problem is either that too many of our school systems are undernourished or that the desegregation problem is not subject to solution so long as local governmental units exercise autonomy over their school systems. In either event, I do not expect that the solution is to be found in a simple rule of equality of educational opportunity on a statewide basis.

It is true that such a command could be obeyed, once the state takes control of the taxing and spending power, by raising all the deprived areas to the level of the best. Given the problems of state finances, that is not a likely result. Indeed, the rule might be most easily complied with by reducing all the school systems within the state to the status of the lowest common denominator. But the more likely result would be some improvement of the worst at the expense of the best. It is 
highly doubtful in my mind that the elimination of excellence is an appropriate price to pay for the symbol of equality. ${ }^{2 \pi}$ (I put to one side temporarily the question whether such an achievement is possible.) William James' epitome of the critics of democracy can hardly be our objective. "Democracy is on its trial," he said, "and no one knows how it will stand the ordeal. ... What its critics now affirm is that its preferences are inveterately for the inferior. So it was in the beginning, they say, and so it will be world without end. Vulgarity enthroned and institutionalized, elbowing everything superior from the highway, this, they tell us, is our irremediable destiny . . .."28

So long as our problem is what it is, I submit that we are-or should be-seeking not an equalization of educational opportunity, but a raising not only of our lowest standards but of our highest. In short, our objective is-or should be-quality, not equality. But it could be argued that by putting everyone in the same boat, we force the influential members of our society to see to the improvement of their own lot by improving the lot of all. The difficulty with this argument is, as I shall again suggest later, that for the affluent, there is, as yet, no obligation to remain in the same boat, even after the Supreme Court has issued its command for equality.

In short, we are really concerned with what lawyers would once have called substantive due process, that is, the establishment of those minimum standards that are worthy of our society or the society to which we aspire. And there are advantages in thinking in these terms rather than those of equality or equal protection of the law. Such an approach would not require the elimination of local government autonomy. It would leave unscarred the very few school systems that now approach our ideas of excellence. It would permit the concentration of effort in the areas where it is most needed.

Let me elaborate the last point just a bit. Equality is Janus-faced. Especially if a simple standard is to be used, and I submit that one would have to be used to effectuate the suggested principle, special treatment for the specially needy will be made more difficult rather than less difficult under a doctrine of equality. Worse than that, if the immediately apparent rule, one of equality of expenditure, is adopted, I submit that a given unit of money spent on a big city slum school will not be as effectively used toward the education of students as the same unit expended on the school in the affluent suburbs. The impoverished inner-city school systems are essentially in need, not of equality of treatment, but of preferential treatment. 
I repeat that the demand for a constitutional principle of equal educational opportunity to be derived from the equal protection clause is not directed toward the problems in education from which our society is suffering.

\section{The Problem of the Wrong Means}

When Edward H. Levi, in his talk at the dedication of the new Earl Warren Legal Center at Berkeley, mentioned the problem with which we are concerned here, he said that the proper forum for finding a solution was not a conference but a research center. ${ }^{29} \mathrm{He}$ was, of course, right, that conferences do not supply solutions for such basic problems. But the same reason that makes it unlikely that a conference will provide solutions makes it unlikely, even Mr. Levi to the contrary notwithstanding, that the judiciary is going to afford an answer. And my third point of difficulty with the suggested constitutional doctrine of equality of educational opportunity is that the Supreme Court is the wrong forum for providing a solution. But I must warn you against my personal bias. Mr. Levi finds the "accomplishment [of the Supreme Court] . . . awesome."30 I find it awful. But even he conceded "that many of the decisions point directions for work which cannot be accomplished by the Court itself." 31 Let me suggest some reasons why I think this would be one of the problems that the Court should leave to others-at least for some time longer-to bring to solution.

\section{Looking Backward at the Trinity}

This is, of course, not the place to assay the efforts of the Warren Court. But it might not be inappropriate to examine the success or failure of the three principal lines of decision on which the proposed constitutional principle must rest.

I suggest that the ingredients for success of any fundamental decision based on the equal protection clause are three, at least two of which must be present each time for the Court's will to prevail beyond its effect on the immediate parties to the lawsuit. The first requirement is that the constitutional standard be a simple one. The second is that the judiciary have adequate control over the means of effectuating enforcement. The third is that the public acquiesce-there is no need for agreement, simply the absence of opposition-in the principle and its application.

a. The Reapportionment Cases. The reapportionment cases, to the

29 Levi, The University, the Professions, and the Law, 56 GALIF. L. REv. 251, 259 (1968). $30 \mathrm{Id}$. at 257.

31 Id. 
surprise of many, including myself, have been enforced with relatively great success. Except for what law in historical perspective must deem negligibly short periods of delay, the Court has had its way. I submit that this has been possible, first, because the Court ignored the complexities that would concern political theorists about the nature of representative government and imposed a simple, easily determined, and readily observed standard: one man-one vote. The Court has displayed neither the desire nor the will to complicate its job by variations of its theme. In essence the rule is an expression of Dr. Seuss' admirable proposition that "a person's a person, no matter how small." The only price of simplicity is the elimination of values of ancient lineage in American political life. But then it has long been recognized that the cost of egalitarianism is the suppression of individualism. And when the Court is now prepared to go to the one extreme, as an earlier Court was prepared to go to the other, simplicity of rule is of the essence of success.

A simple rule is not by itself sufficient to assure success. The second important ingredient in the reapportionment cases has been the unwillingness of any large segment of the population to do battle with it. I was convinced, before the announcement of the reapportionment decision, that there was no popular groundswell demanding reapportionment of state legislatures. I could think of no appeal to the people by any individual or group that sought popular support in exchange for the promise of such franchise reforms. Where that kind of demand exists, there is seldom need for Supreme Court intervention to bring about the change. So, too, after the decisions, there was no widespread clamor to fight the rule. And the politicians were able to make their deals within the judicial processes no less easily than outside them. Any state that really wanted to put its back up and prevent the Court having its way could have done so, within the terms of the Court's doctrine, by providing elections at large for all of its legislators. Such action would have been in keeping with the simple principle of one man-one vote-mathematically it is the most consistent formula-but totally destructive of the objectives sought by the Court, which certainly anticipated a result that would afford representation for minorities. The second ingredient of success in the reapportionment cases then was public acquiescence.

An aside on the reapportionment problem may be in order here. It should be noted that, to the extent that any voice in the legislatures of the states has been strengthened by reapportionment, it is the voice of suburbia, the least likely, I submit, to contribute to the effectuation of a concept of equal educational opportunity. 
The third element, judicial control, was not really present in these cases. The judiciary has no adequate sanctions that it could have brought to bear on recalcitrant states. It didn't need them because of the failure of opposition. The states could have thumbed their noses at judicial orders in the same way that individuals have shown contempt for the contempt power. Fortunately the decline of the "rule of law" has not yet extended to the actions of all American states.

b. The Criminal Procedure Cases. The criminal procedure cases, too, have been successful, to the degree that the courts controlled an effective sanction. That is, where the rule is simple, as in the need to supply transcripts, and the sanction for the failure to comply is the release of the defendant without regard to his guilt or innocence, the courts have had no problem in enforcing the Supreme Court mandate. But it should be noted that no rule of equality has been extended to the right to counsel cases. There the Court has supplied only a due process standard, an assurance that some lawyer will be supplied for a person who cannot afford to hire his own. Only if we are to assume-as I am sure that some are ready to assume-that all lawyers are fungible can it be said that equality of legal services has been made available without reference to the wealth of the individual. Mr. Justice Frankfurter's antediluvian counsel of despair in Griffin $v$. Illinois may perhaps be noted here:32 "[A] State need not equalize economic conditions. A man of means may be able to afford the retention of an expensive, able counsel not within reach of a poor man's purse. Those are contingencies of life which are hardly within the power, let alone the duty, of a State to correct or cushion." I have no doubt that we are headed toward a society in which it will be held that such contingencies of life are not only within the duty but also within the power of the state to cushion. But we have not yet achieved such nirvana. The two elements present in the criminal administration area have been simplicity of rule and capacity for judicial enforcement.

c. The Desegregation Cases. When we turn to the school desegregation cases, the problem most closely analagous to the one we are considering here, we find a more dismal picture of what must be acknowledged to be the Supreme Court's failure rather than its success. The New York Times in its annual educational survey for 1968, thirteen and one-half years after Brown v. Board of Education, suggests that we are hardly any further along the line toward school desegregation than we were in 1954.

Certainly Brown's standard afforded something less than the simplicity of the one man-one vote slogan. But it was not only the complexity of the rule that has prevented its success. Both of the other 
required ingredients were also lacking. I expect that the essential reason for failure is to be found in the fact that the American public, whatever its pious declarations, has not been prepared to accept the Supreme Court's notions of its constitutional obligations. And I would add that in no small measure this has been due to the idea-however true or false-that integration would lead to a lowering of the quality of an already inadequate educational system. This should give some pause to the equal educational opportunity adherents. But whatever the cause, where possible, state and local authorities have successfully warded off the integration of their school systems. Where the governmental resistance was subdued, individual parents managed, to a great extent, to effect an escape from the imposition of the rule, either by moving to areas where integration was not feasible, or by retreating to private schools. (Never has religious school education at the grammar school level seemed so highly prized as since the decision in Brown.) The Washington, D.C., example is too much with us. And everything that Judge Skelly Wright can do will not afford an integrated school system for the Nation's capital. ${ }^{33}$ All that he can accomplish is to assure that the brighter students receive no better education within the system than the other students.

As I have suggested, it is perhaps because of the fact that local governmental units, especially those located in metropolitan areas, cannot or will not bring about racial desegregation that some are looking to the equal educational opportunity concept to break down the municipal boundaries in order to include suburban areas under the same umbrella as that which covers the slum schools. Absent a reversal of the Court's decision in Pierce $v$. Society of Sisters, ${ }^{34}$ however, the escape route of private education will not be closed. And a reversal of that decision will arouse the opposition not only of the suburbanites but of organized religions as well.

The fact of the matter is that in Brown the Court proposed a solution that it could not enforce without the acquiescence of the community. For, as Marshall said of the Constitution in Ogden v. Saunders, "Its language is the language of restraint, not of coercion." The Court's powers are essentially negative, not affirmative. The weaknesses that caused Hamilton to denominate the Court as "the least dangerous" branch of government are the weaknesses that prevent the enforcement of school desegregation:36 "The judiciary ... has no influence over either the sword or the purse; no direction either of the strength or of

33 Hobson v. Hansen, 269 F. Supp. 401 (D.D.C. 1967).

34268 U.S. 510 (1925).

3525 U.S. (12 Wheat.) 212, 351 (1827).

30 THE FEDERALIST, No. 78 (Hamilton). 
the wealth of society; and can take no active resolution whatever. It may truly be said to have neither FORCE NOR WILL, but merely judgment; and must ultimately depend upon the aid of the executive arm even for the efficacy of its judgments."

\section{Looking Forward to the Millennium}

Hindsight is usually more accurate than foresight. To predict the unenforceability of an equal educational opportunity proposition would be foolhardy. The reapportionment cases should afford a caution against such dire prophecy. Mr. Justice Frankfurter told us that legislative reapportionment was beyond the ken of the judicial power ${ }^{37} \mathrm{He}$ has been proved wrong. And I have never claimed to attain his capacity for wisdom. But this is no reason for not canvassing some of the diffculties that such a constitutional doctrine may evoke.

a. Simplicity of Rule. Equality has never been adequately defined as a general legal concept. ${ }^{38}$ It is even more difficult to afford definition in the context of a particular problem such as that posed by the notion of equal educational opportunity. Mr. Wise has dealt with the matter at length, without, I think, affording a simple guide that the courts may adopt, unless it be the guide of per pupil expenditures. ${ }^{39}$ That this is the most likely measure to be used is also indicated by the statistics offered by Mr. Levi when calling the attention of Chief Justice Warren and the Earl Warren Legal Genter to the problem. "The average current expenditures in 1965 for the East South Central states," he tells us, "was 354 dollars per pupil in the primary and secondary public schools. The comparable figure was 732 dollars for the Middle Atlantic states. . . . These discrepancies also occur within a single state. They occur between suburbs surrounding a single city. For example, the expenditure per high school pupil in a suburb to the north of Chicago is 1,283 dollars; in a suburb to the south of the city it is 723 dollars. . . . Is there reason to believe that the opportunity for required education is really equal when there are these extraordinary differences . . . which occur between suburbs of the same city within the same state? And is this discrimination in the operation of the most important function of state and local government to be justified because this is the way the ball bounces; that is, that is how state action happens to collect and happens to allocate funds for the education it requires of all?"40

The dollar expenditure standard is indeed a simple one. It is also

37369 U.S. at 267.

38 See the references collected in Karst \& Horowitz, supra note 23, at 76 n. 130.

39 See note 3 supra.

40 Levi, supra note 29 , at 258-59. 
unfortunately gross. It has its vices as well as its virtues, especially since, as the sole standard it would continue, if it would reduce, existing inequities, even if it would prevent an exacerbation of the difficulties derived from the present separation between the best school systems and the worst. Nor does it afford a basis for the inundation of the worst schools with the best resources that society can marshal, which many believe to be the sole hope for an answer not only to the educational problem but to many of the problems that presently plague our society.

When Mr. Levi suggested that the answer was not to be forthcoming from a conference, he recognized the complexities of the problem that also put it beyond the reach of a simple judicial declaration.

b. Judicial Control of the Means of Enforcement. The judiciary is extremely efficient at wiping a statute off the books. It is quite good at rewriting an existing statute so as to frame a rule that it would have legislated had it been a legislature. But it is not very strong on creating legislation $a b$ initio, except where it falls within its province of administering criminal justice. Given even the least complex measure of the proper standard of equality, dollar equivalence, how can it bring about the necessary change? For the principle calls for a fundamental revision of state governmental structure.

The Court, therefore, cannot leave with the local unit the discretion as to how much it is to tax its constituents and what portion of that amount is to be devoted to educational purposes. Will it then command that all educational expenditures shall be made by the state and no local government unit shall supplement that grant? Will it tell the state how it shall raise the necessary revenues?

Assuming it manages a transfer of responsibility for educational systems to the central government of the state, will it fix a minimum that must be spent on each pupil? If not, but if the amount fixed by the state legislature is above the minimum theretofore prevailing, will the state be able to provide those educational facilities in public schools that are now available in its best school systems? If not, will there be some way of keeping the children of the more affluent groups within the public school systems? If the more affluent groups remove their students from the public school systems, will the notion of equality as a means of protecting the poor be effective? (As of the moment, for example, the community in the neighborhood of the University of Chicago is about as heavily taxed for educational facilities as even the more affluent northern suburbs. But the children of the community are to a very large extent receiving their formal education through private schooling.) Would a single standard, throughout the state, but 
a low one, not be the inevitable result of efforts by the Court to dictate the means of achieving equal educational opportunity?

c. Public Acquiescence in a Rule of Equal Educational Opportunity. Each of the questions asked above is also relevant to the issue whether it is possible to secure equal educational opportunity and to secure the necessary acquiescence of the public. Certainly those who will not expect their children to fare as well under the new system as under the old are not likely to take kindly to the change. And, if it should drive their children out of the public school systems, can you expect them voluntarily to levy the taxes, even through the central state government, necessary to a decent standard of education? The capacity of the parents of parochial school students to thwart bond issues necessary to public school survival has been demonstrated over and over again and affords an object lesson.

Where are you to find your men and women of good will to support such a change? One might have thought that they existed in the rather selective white community that lived in Washington, D.C. But that thought was dissipated by their behavior following the desegregation decisions. One might think that they exist among the enlightened members of the University of Chicago faculty, but they have already eschewed the public schools for their children in favor of the Laboratory School of the University of Chicago where, I expect, the per pupil expenditure is far in excess of the northern suburb that was mentioned in Mr. Levi's talk. And if, as the Brown case certainly indicated, one of the ingredients of adequate educational opportunity is the availability of good students, how does the Court propose to keep them in the public school systems? To date the hope has been based on local autonomy. But when that is gone?

\section{3. "Run the Flag Up the Pole. See if Anyone Salutes"}

Complex problems-and the deficiencies of our educational system are certainly those-do not lend themselves to ready solution by judicial fiat. Unless equality is an end in itself, regardless of the diminution in educational values, the question of the desirability of a Supreme Court edict on this grave issue is certainly dubious. Of course, these platitudes of doom and gloom may be totally inaccurate. "Nil desperandum," Horace told us. "Hope to the end," the Bible says.

Let me then put a different question. Are there values to be achieved by a Supreme Court decision that would merely state the goal to which we aspire, even if it did not help achieve it? Certainly there are arguments to be made for such a decision. "The public has come to expect 
the Court to intervene against gross abuses. And so the Court must intervene." 11

It might be said that some part of our government certainly should seek a solution to the deplorable educational conditions that exist. A display of national conscience by those who have appointed themselves to display the national conscience could supply the symbol or banner round which men of good will could rally forces to fight the good fight.

It might be argued that the Supreme Court of the United States is really the schoolmaster of the Republic ${ }^{42}$ and if it cannot command, it can at least educate the American people about what they need to do to improve the educational systems of the country.

Finally, it might be said that if the evils of the present systems are not reduced by such a Supreme Court decision, they are not likely to be aggravated by such a judgment, so there is everything to gain and nothing to lose.

There are, however, difficulties with these propositions as well. First, as I said earlier, the problems are not really problems of equality, and to frame the issue in these terms is to raise the wrong banner and to miseducate the public. Second, and more important, is the fact that real harm can come from a futile display of morality by the Court by raising expectations that cannot be met. For, of the Supreme Court, it might already be said, to quote my favorite author:

And be these juggling fiends no more believ'd,

That palter with us in a double sense;

That keep the word of promise to our ear,

And break it to our hope.

A court that has used up much of its credit in the bank of public confidence is not likely to provide such leadership. Much of the civil strife that has wracked the nation in recent years has been blamed on the failure of government to keep its promises. John A. McCone's report on the causes of the Watts riots pointed this up. In testifying before the Senate Judiciary Committee investigating the riots of last summer, McCone refused to identify a single cause. He listed several, but most important was "a long period of expectation that began in $1954^{\prime \prime 4}$ with the school desegration cases: great expectations without fulfillment. He also pointed out what we all learn anew every day, that disrespect for law is mounting. An empty Supreme Court decision would certainly not help.

41 Note 23 supra.

42 See Lerner, The Supreme Court as Republican Schoolmaster, 1967 Sup. Cr. REv. 127.

43 See 25 CoNG. Q. WeEkLY Rep. 1658 (1967). 
Finally, one of the difficulties with resort to litigation to solve such problems as confront us is that we thereby tend to absolve from responsibility those more competent and appropriate to afford solutions. The federal and state executives have the resources for the necessary research to develop appropriate answers. (John Gardner and Edward Levi have reported the failure of the universities in this regard. ${ }^{44}$ ) The national and state legislatures have the capacities to supply the wherewithal to put the plans into effect. The judiciary has neither. Responsibility is a concomitant of power. Let's place the responsibility where it belongs. Let's permit the states an opportunity to experiment with different answers to these difficult problems and free them to undertake the experiment. Perhaps after a consensus has been developed as to what the right answer is, or the right answers are, the Supreme Court will be in a position to put them into effect. As of now, I think it is too early for the Court to announce the doctrine of equal educational opportunity. But since the Court acts on the premise that neither logic nor experience is the proper base for constitutional law, I have little expectation that it will suddenly embrace "the passive virtues." 45 On the other hand, I do seem to recall that the Court recently rejected the opportunity to resolve the problems of the Viet Nam War.

44 Levi, supra note 29, at 252.

45 Bickel, The Supreme Court, 1960 Term, Foreword: The Passive Virtues, 75 Harv.' L. REv. 40 (1961). 